\title{
Agency accused of 'illusion of integrity'
}

\section{WASHINGTON DC}

The US National Institutes of Health (NIH) has successfully switched to a new ethical culture and is spending millions on ensuring that rules about employee investments and outside activities are obeyed - according to a top agency official.

"There have been some bumps in the road, but most people would say it has gone reasonably well," says Raynard Kington, deputy director of the biomedical agency, which is based in Bethesda, Maryland.

Not everyone agrees. Kington was speaking to Nature two days after a hearing on 13 September in which unhappy congressmen grilled him and other agency officials. One described the NIH as an "ethical Potemkin village where a hollow system appears to provide the illusion of integrity".

"The NIH has changed its rules and that's a good thing, but they don't appear to really be doing anything to enforce the old rules against their most serious transgressors," said Republican congressman Joe Barton of Texas, chairman of the House Committee on Energy and Commerce. The committee's investigative subcommittee had summoned Kington and others to raise concerns about $\mathrm{NIH}$ management.

New ethics rules came into force at the agency one year ago (see Nature 437, 9; 2005), after a series of revelations about lucrative consultancy payments from companies collected by senior NIH scientists, often as they worked with or promoted the companies' drugs. Under pressure from Congress, NIH director Elias

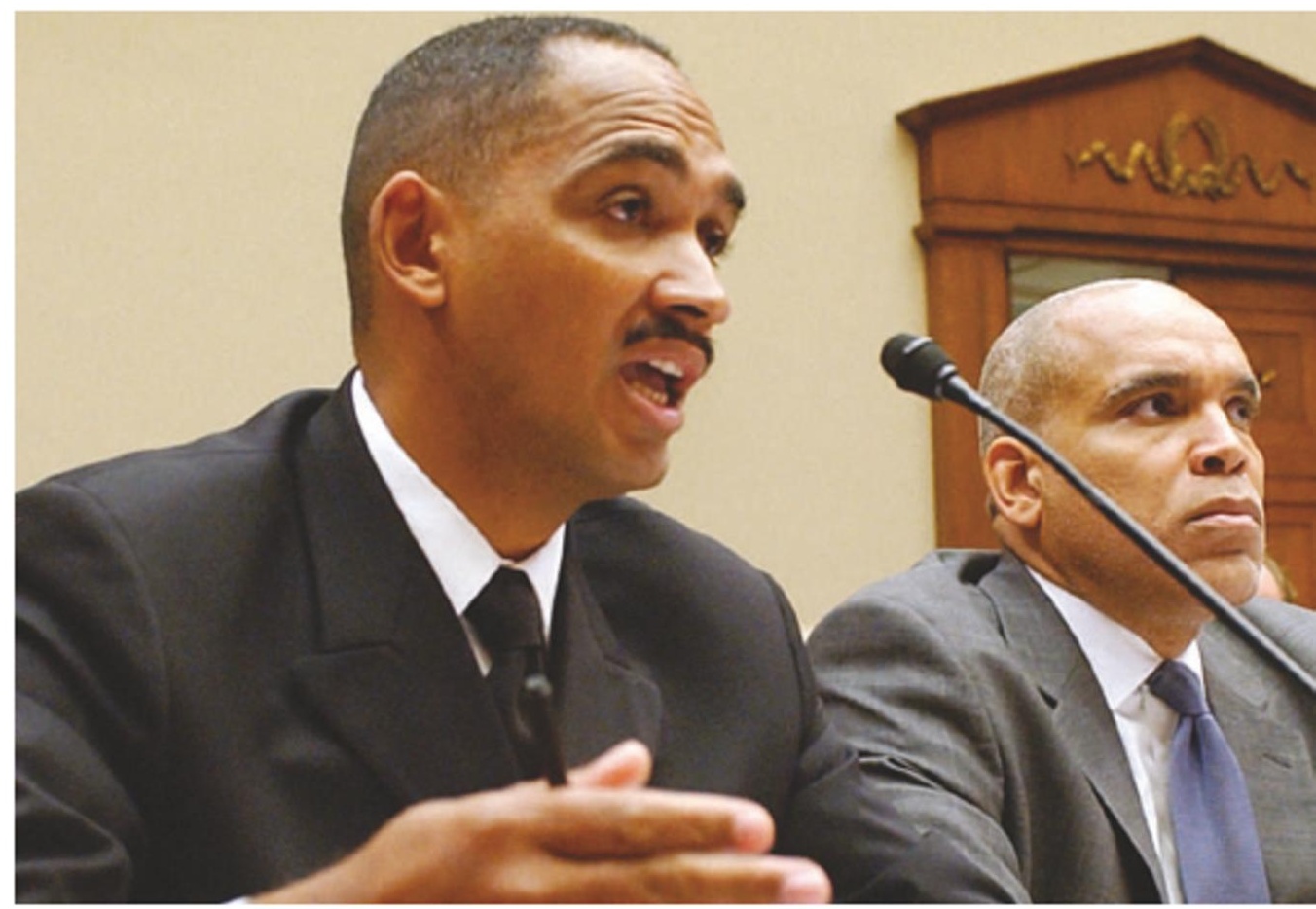

Zerhouni banned employees from doing any outside consulting for pharmaceutical and biotechnology firms. The new rules also force senior scientists to limit stockholdings in biomedical companies to $\$ 15,000$. No scientists may hold shares in companies directly related to their research.

Kington told Nature that the agency has had "very high compliance with the new rules" generally the rules 'don't change most people's

\section{Scientists hit back at the press}

In an unusual attack, more than 100 infectious-disease experts have signed an editorial criticizing a $\operatorname{los}$

Angeles Times article that, they contend, unfairly impugned one of their colleagues.

The commentary by 109 scientists from 16 countries was published last week by Cinical Infectious Diseases. It attacks a 16 July article by reporter David Willman that examined two trials of antifungal agents, led by Thomas Walsh of the National Cancer Institute. In the past, Walsh has received fin ancial support from the drugs' makers.

The scientists say that Willman maligns Walsh by implying that he used inadequate doses of control drugs to make the new drugs seem more effective. They also dispute what they describe as Willman's implicit suggestion that subjects without fungal infections were inappropriately included in the trial. "It is our responsibility to stand up for clinical research and for a colleague whose integrity has been very unfairly attacked," says corresponding author Elias Anaissie of the University of Arkansas for Medical Sciences in Little Rock. Willman, a Pulitzer prizewinner who first exposed lucrative consulting contracts among senior researchers at the National Institutes of Health (see Nature 426, 739; 2003), is unmoved. "Anaissie et al. fail to citea single inaccuracy in my work," he says. "Our coverage has brought to light matters of public importance." He notes that questions about the trials were first raised by others in the field (see, for example, N Engl J.Med.341, 1152-1155; 1999). and that he hasn't had to take any disciplinary action. He adds that the agency is investing several million dollars in improving relevant databases, and that he is about to hire a chief ethics officer to monitor compliance.

Within the NIH there seems to be resigned acceptance of the rules. One senior agency scientist, who asked not to be identified, says that day-to-day life. The NIH is still a really good place to work. You can do your research.

But there has been an impact on morale. "We feel that Zerhouni didn't cover our backs," says the scientist. "Admitting we had to change the rules - it was almost like tacit agreement that there were pervasive problems with the system. And I don't think that any of us feel that was the case." NIH spokesman John Burklow counters that view. ${ }^{\alpha}$ Dr Zerhouni defended the agency and its scientists through public statements and at congressional hearings, he says.

At last week's congressional hearing, the agency was tackled about two researchers who remain on the NIH payroll despite recommendations from their institute directors that they be fired. An internal investigation found that Trey Sunderland, an Alzheimer's researcher, accepted more than $\$ 700,000$ in consulting fees without disclosing them to his bosses, in violation of existing NIH rules. And Thomas Walsh, an infectious-disease specialist, received more 


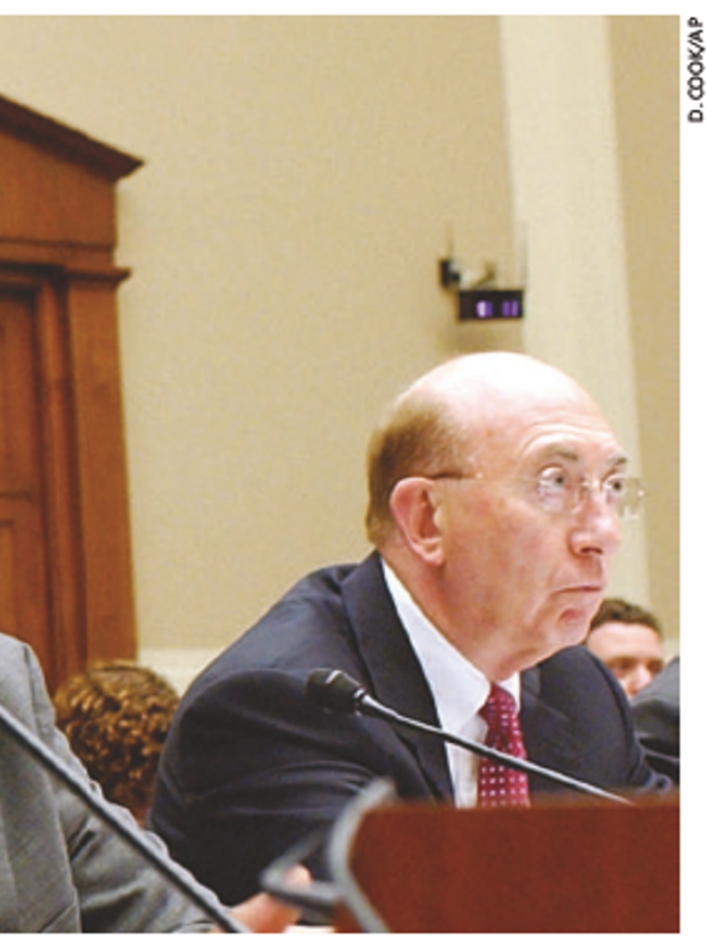

John Agwunobitestifies at a congressional hearing to evaluate ethics reforms at the NIH.

than $\$ 100,000$ in unapproved consulting and speaking payments from 25 companies (see 'Scientists hit back at the press'). Both men have declined to comment.

The NIH doesn't have the authority to fire either of them because they are formally employed by the Commissoned Corps, a branch of the Public Health Service. To dismiss them, the corps must convene a board of inquiry. John Agwunobi, assistant secretary for health, told the subcommittee that it did so for Sunderland early this year, but added that because criminal charges are being considered against Sunderland, the board has been put on indefinite hold. Agwunobi, who oversees the corps, said that a board of inquiry was convened early this month to hear the Walsh case.

That didn't seem to satisfy his interrogators. "In both these cases, we are troubled about whether the NIH and the Commissioned Corps acted appropriately," said Republican congressman Ed Whitfield of Kentucky, subcommittee chairman. "Both the corps and the NIH seem passive, taking the minimal steps to enforce the rules that are the foundation of maintaining publictrust."

Meredith Wadman

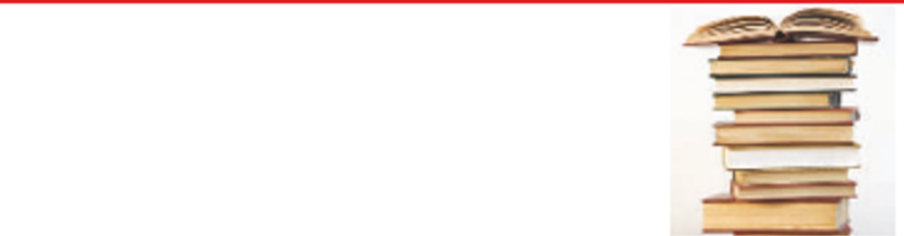

TEXTBOOK FREE FOR ALL Wiki-project aims to pool knowledge in free online texts.

www.nature.com/news
TOKYO

On1 September, Yasuo

Kawas aki, a 42-year-old assistant professor at Osaka University, was found dead in his lab after ingesting poison. The investigation into the case so far has left many questions unanswered - including whether the death was connected to a recently withdrawn article on which Kawas akiwas a co-author.

That paper suggested that a type of DNA helicase called MCM2p plays an important role in DNA replication (W. Nakai et al J. Biol. Chem. 10.1074/jbc. M603586200; 2006). It was published online on 12 July. Buton 2 August, the journal marked it as "withdrawn".

Osaka University began an investigation on 9 August into whether the paper contained false data. In the midst of the inquiry, Kawasaki's body was found - police suspect that his death was a suicide, although they are still working on the case.

Many who knew Kawasaki have expressed surprise and shock at his death. "Hewas a talented young scientist," says John Diffley, an expert in DNA replication at Cancer Research UK's London Research Institute, who knew him since Kawas akiwas a postdoc at Cornell University inlthaca, New York. "His career seemed to be going very well."

Hisato Kondoh, dean of the Graduate School of Frontier Biosciences at Osaka, dismisses any suspicion that Kawasaki mighthave killed himself after being caught engaging in scientific misconduct. "The person who committed suicide was not involved in scientific fraud," he says. Kondoh declined to comment further on the ongoing investigation into the paper, saying only that the results will be made public when they are complete.

But the events leading up to the withdrawal of the paper are far from clear. Nature has learned that Akio Sugino, head of Kawasaki's lab and corresponding author on the paper, had submitted it for publication withoutchecking with all of his $\mathrm{CO}$-authors.

According to Japanese press reports, Kawasaki subsequently found that some of his data had been changed, so he asked Sugino to withdraw the article, and informed Kondoh. The university is also investigating several other related papers from the group.

Sugino was notavailable for comment. Robert Simoni, deputy editor of the Journal of Biological Chemistry, also declined Nature's request for information aboutwhy the paper was withdrawn, and refused to clarify how a withdrawal differs from a retraction. Butscientists in the field describe Sugino as well respected and of high integrity - "a venerable old hand at DNA replication" as Diffley puts it.

Some of the details surrounding Kawasaki's death are also mysterious.

Although suicide is relatively common in Japan, the cause of death tends to be hanging or gassing. Kawasaki died from ingesting sodium azide, a white, odourless solid that causes convulsions and respiratory failure within minutes. Such a method of suicide is extremely rare in Japan, according to National Police Agency statistics.

The suicide note was also unusual - rather than being handwritten, it was printed out from a computer. And despite being addressed to his family, it was found, along with an empty container of sodium azide, in the lab where Kawasaki's body was discovered. According to the Os aka police department, the note was an explanation of Kawasaki's emotions. It did not mention the withdrawn paper mention the withdrawn paper at work. It began: "Things at work have settled down. I want to resolve the problem."

When askedabout rumours that there was intense pressure on Kawasakibefore his death, Kondoh said that measures had been in place to protect whistleblowers since the beginning of the incident. He added that there is no evidence of a connection between the app arent suicide and the withdrawn paper.

Japanese universities often respond slowly to suspicions of fraud, and aren't known for their trans parency. Diffley says he now hopes Osaka will buck that trend. "I really hope the university gets to the bottom of whathappened," he says. "It will be a shame if itis a whitewash." Hepoints out that without a definitive investigation result, rumours of misconduct could blight the whole group. "The careers of many scientists will be affected."

Kiyoshi Kurokawa, president of the Science Council of Japan, agrees."Japanese universities and institutions may not always take the right approach to resolving problems," he says. "But do they realize that the science community around the world is watching?"

Ichiko Fuyuno and David Cyranoski 